\title{
Crude Oil and the Nigeria Naira Exchange Rate
}

\author{
${ }^{1}$ OMEKWE, Sunday Omiekuma Paul, ${ }^{2}$ OBAYORI, Joseph Bidemi \\ ${ }^{l}$ Department of Economics, Faculty of Social Sciences, University of Port Harcourt, Nigeria \\ ${ }^{2}$ Department of Economics, Faculty of Social Sciences, Nnamdi Azikiwe University, Awka, Nigeria.
}

\begin{abstract}
The paper examined crude oil and the Nigeria naira exchange rate. Crude oil is a natural resource found beneath the water table usually in the delta region or in the sea and ocean. Oil as a hydrocarbon was first found and drilled in Oloibiri in Bayelsa State in 1956, and has become the basic source of Nigeria's foreign earnings and therefore its foreign exchange. Exchange rate is the value of another country's currency compared to that of your own. But the ups and downs in the price of crude oil has put the Nigerian economy at the edge of the sword. Moreover, since the announced global slump in oil prices, governments at all levels (federal, state and local) have had hard times meeting their expenditure needs. Also, the weak value of the naira in relation to the US. Dollar has not help the country economy. This is because, while the stream of income remained the same, one now need more Naira to pay for some commodities abroad. Also, any drop in crude oil prices tends to lead to a weakened Naira against the dollar on the black market. Therefore, in order to have a chance at developing, a country needs to maintain a competitive exchange rate that is not overvalued.
\end{abstract}

Key Words: Oil, Naira, Exchange Rate, Nigeria Overvalued, Devalue

\section{Introduction an Overview}

Copious scholarships have revealed that oil influences economic growth and development in countries. For instance, a study by Boheman and Maxen (2015) on how oil affects economic growth in net-oil exporting countries found that a percentage increase in the price of oil increases GDP growth the following year by 0.145 percent in OPEC member countries and 0.141percent in non-OPEC member countries. Similarly, the importance of oil has made it a most potent weapon within the global economy and one of the strong determinants of the value of the dollar in international market and trade.

Meanwhile, the oil sector accounts for a significant amount of revenue in Nigeria. The sector over the years has become a major contributor to economic growth and development, foreign exchange and reserves to the country in the past decades. This is noticeable with the importance with which Nigeria governments' place on oil through state ownership, control and active participation in the sector through organization such as the Nigeria National Petroleum Corporation (NNPC). But the ups and downs in the price of crude oil has put the Nigerian economy at the edge of the sword.

Moreover, since the announced global slump in oil prices in the late 2014, Nigeria governments at all levels (federal, state and local) have had hard times meeting their expenditure needs, including the common cry by workers that their salaries are being owed by some States and Local Governments for upwards of ten months. Also, the weak value of the naira in relation to the US. Dollar has not help the country economy at all. This is because, while the stream of income remained the same, one now need more Naira to pay for some commodities in Canada and the United States who rates of exchange are US Dollar and British Pound respectively.

Thus, there must be something about the relationship between oil, the value of the Naira and effects on general wellbeing of Nigerians. In theory, economists have explanations and answers for these phenomena. That was why this paper x-ray oil and the rate of naira exchange in Nigeria. 


\section{Concept of Naira and Crude Oil}

The Naira and Kobo is Nigeria's currency, which became legal tender on January 1, 1973. One hundred Kobo makes one Naira(NI).Naira is the Nigeria currency that is legal tender to trade and exchange with the rest of the World currency. On the other hand, oil is a natural resource found beneath the water table usually in the delta region or in the sea and ocean. Oil asa hydrocarbon was first found and drilled in Oloibiri in Bayelsa State in 1956, and has become the main stay/source of Nigeria's foreign earnings and therefore its foreign exchange. Though it forms greater part of Nigeria's GDP and as well contributes more than $90 \%$ of Nigeria's total foreign earnings (Ewubare\&Obayori, 2019).In politics and diplomacy, oil is given tremendous importance in every country of the world. It serves as a gate way for foreign exchange earnings to the exporters of oil (Ewubare\&Obayori, 2019).

The Nigerian economy is dominated by the petroleum industry since the oil boom of the 1970s. Therefore, her economic growth is a function of production and consumption of petroleum products and hence it has a link with the State and oil in Nigeria (Opaleye, Okowa\&Ohale).

\section{Exchange Rate and its Components}

Exchange rate is the ratio at which one money can be swapped for another. In other words, it is the value of another nation's money compared to that of your own (Gbosi, 2019). For the purposes of this paper, exchange rate was defined as the value of the US Dollar compared to that of the Nigerian Naira. When a Nigerian travel to another country, say the US, he/she need to "buy" the local currency, that is, the US Dollar. Just like the price of any commodity or product or good, the exchange rate is the price at which one can buy that currency, in this case, the US Dollar.

There are two components of exchange rate; the domestic currency and a foreign currency. Both can be quoted directly or indirectly. Directly, a unit cost of foreign currency is expressed in relation to local currency. While indirectly, a unit cost of domestic currency is expressed in term of foreign currency. Meanwhile, when the rate of exchange lacks domestic currency as one of the two currency components is known as a cross currency, or cross rate.

Most exchange rates (including the Naira) uses the US dollar as the base currency and other currencies as the counter currency. But the Euro and Commonwealth currencies like the British pound, Australian dollar and New Zealand dollar are exempted. For example in Nigeria,US\$1 = \$300 (Black Market) $=\$ 199$ (Official fixed CBN rate). Here the base currency is the US dollar and the counter currency is the Nigerian Naira. In Nigeria, this exchange rate would be termed a direct quotation of the Nigerian Naira, since prices of goods and services in Nigeria are expressed in the Nigerian Naira; therefore the price of a US Dollar in Nigerian Naira is an example of a direct quotation for a Nigerian resident. $\$ 1=$ US $\$ 0.0033$ US $\$=0.3$ US cents (using the black market rate). Here, because the base currency is the Nigerian Naira and the counter currency is the US Dollar, this would be an indirect quotation of the Nigerian Naira in Nigeria. If US $\$ 1=.70$ British Pound, and US $\$ 1=\$ 300$, it follows that $¥ 300=.70$ British Pound or 1 British Pound $=\$ 518.5$. For an investor based in Europe the US Dollar to the British Pound exchange rate constitutes Cross Currency Rate (CCR) since neither currency is the domestic currency. Note here that although Britain is a European country, its currency, the British Pound, is not denominated in the European Euro.

\section{Determination of Exchange Rate}

The Gold Standard of Exchange Rate: In between the period of 1870 and 1914, currencies were linked to gold. Thus, the value of a local currency was fixed at a set exchange rate to gold ounces. This was known as the gold standard. This allowed for global stability in currencies and trade. But this was abolished during the First World War. 
International Monetary Fund (IMF): There was general concession that currencies would be fixed, or pegged to the US\$ and was then fixed to US\$35 per ounce of gold. For example, at that time, the value of the Nigeria Naira would have been directly linked with the value of the U.S. dollar. So, if one needed to buy the Naira (Nigeria was using the British Pound as its currency at the time), the value of the Naira (Pound) would be expressed in US\$, as it determined the gold. Therefore, any further change in the value of a country currency was done with the knowledge of IMF. The peg was maintained until 1971.

Foreign Reserves: Foreign reserves serves as resources held by the central banks of countries or other monetary authorities that are mainly held in foreign currencies. These resources include foreign marketable securities, monetary gold, special drawing rights (SDRs) and reserve position in the IMF. The main purpose of holding foreign exchange reserves is to make international payments and guide against exchange rate risks. It also influences the rate of exchange of its country.

\section{Relationship between Economic Growth and Exchange Rate}

The relationship between exchange rate and economies was considered less than two perspectives, namely, Transactional demand for goods and services and the Exchange rate as well as Transactional Demand for Money and Exchange Rate.

\section{a. Transactional demand for goods and services and the Exchange rate}

There is a direct relationship between exchange rate and the determination of relative prices of goods and services. A country that exports goods and services will prefer a lower value on their currencies, as this will encourage higher demand for goods and services, thus creating a favorable balance of payments or current accounts, and this ultimately therefore generates employment and economic growth. But the reverse is the cases for countries that imports goods and services and therefore discourage demand for foreign goods. Thus a lower exchange rate lowers the price of a country's goods for consumers in other countries, but raises the price of imported goods and services, for consumers in the low value currency country. The transaction demand has a relationship with a nation macroeconomic aggregate.

\section{b. Transactional Demand for Money and Exchange Rate}

Increased demand for a nation's currency can also be due to increased speculative demand for money. The market for trading in international bonds, stocks and all forms of financial instruments has increased globally with virtually every country setting up stock exchanges. It is common knowledge that all activities in these markets centre on speculations. Thus, such uncertainties are inimical to the growth of an economy. Speculative demand for currency termed "forex" is the largest market in the world.

\section{Recommendations by Experts on Ups and Downs of Naira Exchange Rate}

Some economist and financial experts have faulted Nigeria government position on the Naira, stressing that the CBN would find it difficult to preserve the currency from further devaluation amid depleting reserves;"

1. Nigeria renowned economist and Chief Executive Officer, Financial Derivatives Company Limited, in person of Mr. Rewane Bismarck averred that forex control by the central bank in conjunction with devaluation will be a savior of the country ups and downs in the rate of exchange.

2. Prof.SheriffdeenTella of OlabisiOnabanjo University, Nigeria, is, however, of the opinion that devaluation of the naira will not be in the interest of an import-dependent nation like Nigeria. This is because Nigeria do not have much products to export.

3. Former CBN Governor, LamidoSanusi said Nigeria needed to devalue the Naira because the CBN might not be able to sustain its current control policies in the long run, especially in the face of depleting forex earnings by the nation. Also, another former CBN Governor, Prof. Charles Soludo, in a paper presented at a forum, said history had shown that forex restriction had not worked in many countries in the past." 


\section{Conclusion}

The paper examined crude oil and the Nigeria naira exchange rate. Crude oil since first found in 1956 has become the main source of Nigeria's foreign earnings and its foreign exchange. But the ups and downs in the price of crude oil has put the Nigerian economy at the edge of the sword. This is because, the global slump in oil prices has affected the Nigerian economy as any drop in crude oil prices tends to lead to a weakened Naira against the dollar on the black market.

Many countries have encountered crises that interjected their growth or never experience grows because they made a bad choice. It is believed that exchange rate policy was one of the keys for a country's development because, it motivate entrepreneurs to go and sell things other than traditional export commodities on the world market, they would also want to invest and expand employment and the economy would grow. At the other extreme, if the country got too much easy money from oil exports, or aid, or capital inflows, then its exchange rate would be driven to a tip where there is no cash to be made from non-traditional sell abroad. Therefore, in order to have a chance at developing, a country needs to maintain a competitive exchange rate (a competitive rate as one that is not overvalued, not as one that is undervalued).

\section{REFERENCES}

[1] Balassa, B., \& Associates. (1982). Development Strategies in Semi-Industrial Countries. Baltimore: Johns Hopkins University Press for the World Bank.

[2] Blanchard, O., Gustavo, A. \&Irineu de Carvalho, F. (2015). Can foreign exchange intervention stem exchange rate pressures from global capital flow shocks, IMF Working Paper (WP/15/159)

[3] Boheman, H. \&Maxén, J. (2015). Oil Price Shocks Effect on Economic Growth - OPEC versus non-OPEC Economies. Lund University, School of Economics and Management.

[4] Ewubare, D.B. \&Obayori, E.L. (2019). Comparative study of the impact of oil rent on healthcare in Nigeria and Cameroon: A three stage methodical approach. International Journal of Science and Management Studies, 2(1), 58-63

[5] Gbosi, A. N. (2019). Managing the Naira (2 ${ }^{\text {nd }}$ edition). Port Harcourt: Sofiata Publishers.

[6] Gustavo, A. \& Camilo, E. T. (2014). Foreign Exchange Interventions and their Impact on Exchange Rate Levels," Monetaria, Centro de EstudiosMonetariosLatinoamericanos, (1), 1-48.

[7] Hope the Naira falls, The Economist (e-publication), January, 30, 2016

[8] Oluwatomisi, M. O.,Oyeaga, P., \&Ogundipe, A. (2014). Oil prices and exchange rate volatility in Nigeria, Journal of Economics and Finance, 5 (4), 01-09

[9] Opaleye, S.S., Okowa, W. \&Ohale, L. (2018). Oil rent and socioeconomic outcomes in selected oil producing countries in Africa. International Journal of Research in Business, Economic and Management, 2(2), 27-43

[10] PUNCH (2016). Punch News Paper, January 28, 2016

[11] Williamson, John. 2003. Exchange Rate Policy and Development. Paper presented to a conference of the Institute for Policy Dialogue, June.

[12] Yinka, I., Xola P.,\&Emeka, O. (2016). Nigeria flirts with economic disaster as Naira control stays, Bloomberg Business (epublication) 